\title{
Large Scale Isolation, Growth, and Function of Porcine Neonatal Islet Cells
}

\author{
Gregory S. Korbutt, ${ }^{*}$ John F. Elliott, ${ }^{\ddagger}$ Ziliang Ao, ${ }^{\star}$ Dean K. Smith, ${ }^{\ddagger}$ Garth L. Warnock, ${ }^{\star}$ and Ray V. Rajotte ${ }^{\star}$ \\ $*$ Surgical-Medical Research Institute and ${ }^{\ddagger}$ Department of Medical Microbiology and Immunology, University of Alberta, Edmonton, \\ Alberta T6G 2 N8 Canada
}

\begin{abstract}
Based upon existing methods of isolating fetal porcine islet tissue, a simple, reliable procedure was developed for the preparation of porcine neonatal islet cell aggregates with a reproducible and defined cellular composition. After $9 \mathrm{~d}$ of in vitro culture, tissue from one neonatal pig pancreas yielded $\sim \mathbf{5 0 , 0 0 0}$ islet cell aggregates, consisting of primarily epithelial cells $(57 \%)$ and pancreatic endocrine cells (35\%). During the culture period, the total $\beta$ cell mass decreased initially, but subsequently increased 1.5 -fold between days 3 and 9. Transplantation of grafts consisting of $3 \times 10^{5} \beta$ cells (1,000 aggregates) under the kidney capsule of alloxan-diabetic nude mice corrected hyperglycemia in $75 \%(10 / 13)$ of the animals, whereas, $100 \%(20 / 20)$ of recipients implanted with $6 \times 10^{5} \beta$ cells $(2,000$ aggregates) achieved euglycemia within $8 \mathrm{wk}$ posttransplantation. Nephrectomy of the graft bearing kidney at $14 \mathrm{wk}$ posttransplantation resulted in hyperglycemia in all recipients, and examination of the grafts revealed the presence of numerous well-granulated insulin- and glucagon-containing cells. The cellular insulin content of these grafts was 20 to 30 -fold higher than at the time of transplantation. These results indicate that the neonatal porcine pancreas can be used as a source of large numbers of viable islet cells, which have the potential for growth both in vitro and in vivo, and exhibit the metabolic capacity to correct diabetes in nude mice. $(J$. Clin. Invest. 1996. 97:2119-2129.) Key words: diabetes mellitus $\bullet$ pancreatic $\beta$ cell $\bullet$ tissue culture $\bullet$ islet cell neogenesis - transplantation
\end{abstract}

\section{Introduction}

The replacement of pancreatic endocrine tissue by islet transplantation offers a physiological approach to precise restora-

This work was presented in part at the 1st International Workshop on Pig-to-Man Islet Transplantation, March 1995 in Stockholm, Sweden and the 5th International Congress on Pancreas and Islet Transplantation, June 1995 in Miami, FL.

Address correspondence to Dr. Ray V. Rajotte, Director, Surgical-Medical Research Institute, 1074 Dentistry/Pharmacy Building, University of Alberta, Edmonton, Alberta T6G 2N8, Canada. Phone: 403-492-3386; FAX: 403-492-1627; E-mail: rrajotte@gpu.srv. ualberta.ca

Received for publication 19 December 1995 and accepted in revised form 8 February 1996.

J. Clin. Invest.

(C) The American Society for Clinical Investigation, Inc.

0021-9738/96/05/2119/11 \$2.00

Volume 97, Number 9, May 1996, 2119-2129 tion of euglycemia in type I diabetics. Within the past five years, several cases have been reported where human islet allotransplantation has corrected basal hyperglycemia, rendering recipients insulin-independent for varying periods of time (1-6). This recent success is attributable to the development of more reproducible methods for isolating and purifying human islets (7-9) and by the provision of an adequate $\beta$ cell mass to achieve insulin independence. If islet transplantation is to become a widespread treatment for type I diabetics, it is clear that the supply of donor organs will become a major limitation. In an attempt to overcome this supply problem, islet tissue from abundant and accessible animal sources are being considered for xenotransplantation (10-17). Pigs appear to meet the necessary requirements for a xenogeneic source of insulin-producing tissue as they breed rapidly, have large litters, and exhibit morphological and physiological characteristics comparable to humans. Porcine insulin is also structurally similar to human insulin and has been used safely for treating type I diabetics for decades.

Unfortunately, despite many reports on the isolation of adult porcine islets, factors such as age, breed, and quality of organs adversely affect the final yield $(18,19)$, and, once isolated, adult porcine islets are fragile and difficult to maintain in tissue culture $(17,20,21)$. The fragility of these islets significantly decreases yields of islet cells particularly when culture procedures are used to reduce graft immunogenicity or when low temperature storage is used to combine isolates from multiple donors. In contrast, tissue culture of collagenase digested fetal porcine pancreas produces viable islet-like cell clusters $(10-12,14)$, which have the ability to cure diabetic nude mice within 2 mo posttransplantation $(11,12)$. A general finding, however, in rat $(22-25)$, porcine $(11,12)$, and human $(26)$ fetal pancreatic $\beta$ cells is that they exhibit a poor insulin secretory response to glucose (22-26), and the onset and maturation of glucose-induced insulin secretion is more evident in the postnatal period (22-25). Although it has been demonstrated that porcine neonatal pancreatic $\beta$ cells are capable of secreting significant quantities of insulin in response to an in vitro glucose challenge $(27,28)$, no studies have examined their growth potential or functional ability to correct hyperglycemia in experimental models of diabetes. The aims of the present investigation were to develop a standardized method for the large scale isolation of porcine neonatal islet cell (NIC) ${ }^{1}$ aggregates, to define the cellular composition of these aggregates, and to assess their growth potential and viability both in vitro and in vivo. The study was undertaken to determine the feasibility of using the neonatal porcine pancreas as a source of insulin-producing tissue for xenotransplantation into human type I diabetics.

1. Abbreviations used in this paper: GTT, glucose tolerance test; NIC, neonatal islet cell. 


\section{Methods}

Media and products. The isolation of porcine NIC aggregates was carried out in HBSS (Gibco, Burlington, Canada) supplemented with $0.25 \%$ BSA (fraction V; Sigma Chemical Co., St. Louis, MO), $10 \mathrm{mmol} /$ liter Hepes (ICN Biomedicals, Inc., Costa Mesa, CA), $100 \mathrm{U} / \mathrm{ml}$ penicillin, and $0.1 \mathrm{mg} / \mathrm{ml}$ streptomycin. Ham's F10 tissue culture medium was purchased from Gibco, isobutylmethylxanthine (IBMX) from ICN Biomedicals, nicotinamide from BDH Biochemical (Poole, England) and theophylline from Aldrich Chemical Co. (Milwaukee, WI). Insulin release experiments were carried out in RPMI tissue culture medium (Gibco). Collagenase (Type V) was obtained from Sigma, and crystalline trypsin, bovine pancreatic DNase, Proteinase $\mathrm{K}$, and RNase A from Boehringer Mannheim (Laval, Canada). Picogreen (P-7581), a fluorescent nucleic acid stain for quantification of double-stranded DNA, was purchased from Molecular Probes, Inc. (Eugene, OR).

Animals. Donor pancreases were obtained from 1 to $3 \mathrm{~d}$-old Landrace-Yorkshire neonatal pigs (1.5-2.0 kg body wt) of either sex. Piglets were anesthetized with Halothane and subjected to laparotomy and complete exsanguination. The pancreas was then carefully dissected from surrounding tissue and placed in cooled $\left(4^{\circ} \mathrm{C}\right)$ HBSS (supplemented as above). Warm and cold ischemia was kept to $<10$ and $<5 \mathrm{~min}$, respectively. Eight glands were initially used to standardize the procurement and isolation procedure. Data were then obtained from 10 consecutive independent experiments, with islet cells prepared from three neonatal pig pancreases for each experiment.

Male, inbred, athymic nude Balb/c mice (age 6-8 wk) were used as recipients of the NIC aggregates (The Jackson Laboratories, Bar Harbor, ME). Mice were rendered diabetic by intravenous injection of $90 \mathrm{mg} / \mathrm{kg}$ body wt alloxan (Sigma Chemical Co.; freshly dissolved in $1 \mathrm{mmol} /$ liter hydrochloric acid) 4-5 d before transplantation. Normoglycemic, age-matched mice served as normal controls. All recipients entering this study exhibited blood glucose levels above 20 $\mathrm{mmol} /$ liter. Blood samples were obtained from the tail vein for glucose assay (Medisense glucose meter; Medisense Canada, Mississauga, Canada). Animals were maintained under virus-antibody-free conditions in climatized rooms with free access to sterilized tap water and pelleted food.

Preparation and culture of porcine NIC aggregates. Each of the glands were cut into fragments of $\sim 1-2 \mathrm{~mm}^{3}$, then transferred to sterile tubes containing HBSS (supplemented as above) with $2.5 \mathrm{mg}$ / $\mathrm{ml}$ collagenase, and gently agitated for $16-18 \mathrm{~min}$ in a shaking water bath at $37^{\circ} \mathrm{C}$. The digest was filtered through a nylon screen $(500$ $\mu \mathrm{m}$ ), washed four times in HBSS, then placed into bacteriological petri dishes containing Ham's F10 tissue culture medium (10 mmol/liter glucose, $50 \mu \mathrm{mol} /$ liter IBMX, $0.5 \% \mathrm{BSA}, 2 \mathrm{mmol} /$ liter L-glutamine, $10 \mathrm{mmol} /$ liter nicotinamide, $100 \mathrm{U} / \mathrm{ml}$ penicillin, and $100 \mu \mathrm{g} / \mathrm{ml} \mathrm{strep-}$ tomycin). Culture dishes were maintained at $37^{\circ} \mathrm{C}\left(5 \% \mathrm{CO}_{2}, 95 \%\right.$ air $)$ in humidified air for $9 \mathrm{~d}$, with the medium and dishes changed the first day after isolation and the medium every second day thereafter.

Characterization of islet cell preparations. After the isolation procedure, and after 3 and $9 \mathrm{~d}$ of tissue culture, recovery and purity of the NIC aggregates was determined on the basis of cellular hormone, DNA, and amylase content. All measurements were assessed from duplicate aliquots of the islet cell suspensions. Hormone content was measured after extraction in $2 \mathrm{mmol} /$ liter acetic acid containing $0.25 \%$ BSA. Samples were sonicated in acetic acid, centrifuged $(800 \mathrm{~g}$, $15 \mathrm{~min}$ ), then supernatants were collected and stored at $-20^{\circ} \mathrm{C}$ until assayed for insulin content by ELISA (Boehringer Mannheim) and for glucagon content by means of radioimmunoassay (Diagnostic Products Corp., Los Angeles, CA). Amylase content was determined in supernatant fractions collected from cell suspensions which were sonicated in supplemented HBSS, stored at $-20^{\circ} \mathrm{C}$, then measured by an enzymatic amylase assay (Beckman Instruments Inc., Carlsbad, CA). For DNA content, aliquots were washed in citrate buffer (150 $\mathrm{mmol} /$ liter NaCl, $15 \mathrm{mmol} /$ liter citrate, $3 \mathrm{mmol} /$ liter EDTA, $\mathrm{pH}$ 7.4) and stored as cell pellets at $-20^{\circ} \mathrm{C}$. Before being assayed, cell pellets were placed in $450 \mu \mathrm{l}$ of lysis buffer $(10 \mathrm{mmol} /$ liter Tris, $1 \mathrm{mmol} / \mathrm{liter}$ EDTA, $0.5 \%$ Triton $\left.\mathrm{X}-100,4^{\circ} \mathrm{C}, \mathrm{pH} 7.5\right)$, sonicated, supplemented with $25 \mu \mathrm{l}$ of Proteinase $\mathrm{K}$ solution $(8 \mathrm{mg} / \mathrm{ml})$, vortexed, and incubated at 65 and $70^{\circ} \mathrm{C}$ for 45 and $10 \mathrm{~min}$, respectively. Lysates were supplemented with $25 \mu \mathrm{l}$ of RNase A solution $(10 \mathrm{mg} / \mathrm{ml})$, vortexed, and incubated for $1 \mathrm{~h}$ at $37^{\circ} \mathrm{C}$. Aliquots of 25 and $50 \mu \mathrm{l}$ were assayed in duplicate by diluting them in $1 \mathrm{ml}$ of DNA buffer $(10 \mathrm{mmol} / \mathrm{liter}$ Tris, $1 \mathrm{mmol} /$ liter EDTA, $\mathrm{pH}$ 7.5) and measuring fluorescence at 490 exc. / $515 \mathrm{em} . \mathrm{nm}$ after the addition of $1 \mathrm{ml}$ of Pico Green reagent (1/200 dilution with DNA buffer). Samples were run in parallel with and diluted in proportion to a seven point $(0-400 \mathrm{ng} / \mathrm{ml})$ standard curve which was generated using calf thymus DNA. To determine DNA content per islet cell, NIC aggregates were dissociated into single cell suspensions by gentle agitation in calcium-free medium containing trypsin $(15 \mu \mathrm{g} / \mathrm{ml})$ and DNase $(4 \mu \mathrm{g} / \mathrm{ml}$, references $29-31)$. A Burker chamber was used for cell counts $(29,30)$, and samples ranging from $2-5 \times 10^{4}$ cells were assayed for DNA content.

The cellular composition of each fraction was determined by electron microscopy and immunohistochemistry using methods similar to that previously described by Pipeleers et al. (32-34). Aggregates were fixed in $2.5 \%$ ( $\mathrm{vol} / \mathrm{vol})$ glutaraldehyde (Millonig's buffer, $\mathrm{pH} 7.2$ ), post-fixed in $1.5 \%$ (wt/vol) $\mathrm{OsO}_{4}$, washed in distilled water, then dehydrated successively in 50, 70, 80, 90, and $100 \%$ ethanol, before embedding in araldite. For electron microscopy, sections were stained with lead citrate and uranyl acetate then subsequently examined in a Hitachi H 7000 (Hitachi Ltd., Tokyo, Japan) transmission electron microscope. In each sample, minimally 100 cells were examined and characterized as exocrine (presence of zymogen granules $>500 \mathrm{~nm}$ in diameter), endocrine (presence of smaller granules typical for $\alpha, \beta, \delta$, or pancreatic polypeptide cells), nongranulated (absence of secretory vesicles), or as damaged (ruptured plasma membranes and/or swollen organelles) $(32,33)$. For immunohistochemistry, the avidin-biotin complex (ABC) method was used with peroxidase and diaminobenzidine as the chromagen. Sections $(1 \mu \mathrm{m})$ were affixed to glass slides by heat, the plastic resin removed with sodium methoxide and counter stained with Harris's hemotoxylin for $2 \mathrm{~min}$, then subsequently stained separately for the presence of insulin- and glucagon-containing cells. In each experiment, a minimum of 15 aggregates randomly selected from three to four different sections were examined. Primary antibodies (Dako Corp., Carpinteria, CA) included, guinea pig antiporcine insulin $(1: 1,000)$ and rabbit antiglucagon (1:100); biotinylated secondary antibodies and the ABC-enzyme complexes were purchased from Vector Laboratories (Burlingame, CA). Primary antibodies were incubated for $30 \mathrm{~min}$ (room temperature), while secondary antibodies were applied for $20 \mathrm{~min}$.

For assessment of in vitro viability, the NICs secretory response to glucose was determined after $9 \mathrm{~d}$ of tissue culture by using a static incubation assay (29). The cultured fractions were recovered from the petri dishes, washed, and aliquots of 50-100 aggregates were incubated for $120 \mathrm{~min}$ in $1.5 \mathrm{ml}$ of RPMI medium supplemented with $2 \mathrm{mmol} /$ liter L-glutamine, $0.5 \% \mathrm{BSA}$ and either $2.8 \mathrm{mmol} / \mathrm{liter}$ glucose, $20 \mathrm{mmol} /$ liter glucose or $20 \mathrm{mmol} /$ liter glucose plus $10 \mathrm{mmol} / \mathrm{li}$ ter theophylline. Tissue and medium were then separated by centrifugation and assayed for their respective insulin contents. The insulin content of the medium was expressed as a percentage of the total content (i.e., tissue plus medium). Stimulation indices were calculated by dividing the amount of insulin release at $20 \mathrm{mmol} / \mathrm{liter}$ glucose $(+/-$ theophylline) by that released at $2.8 \mathrm{mmol} /$ liter glucose. In four independent experiments a portion of the freshly isolated NIC preparation was cultured for $9 \mathrm{~d}$ in the supplemented HAM's F10 medium, but without the addition of $10 \mathrm{mmol} /$ liter nicotinamide, to assess whether nicotinamide influenced the insulin secretory capacity of porcine neonatal $\beta$ cells.

Transplantation and metabolic follow-up. After $9 \mathrm{~d}$ of culture, NIC aggregates were transplanted under the left kidney capsule of Halothane-anesthetized nude mice. Before implantation, the cellular composition of the graft was characterized as outlined above, and to standardize the mass of islet cells transplanted in each experiment, 
Table I. Preparation of Porcine Neonatal Islet Cell Aggregates

\begin{tabular}{|c|c|c|c|c|c|}
\hline \multirow[b]{2}{*}{ Culture period } & \multicolumn{3}{|c|}{ Recovery per pancreas } & \multicolumn{2}{|c|}{ Purity } \\
\hline & Insulin & DNA & Amylase & Insulin/DNA & Insulin/Amylase \\
\hline & $\mu g$ & $\mu g$ & $U$ & $\mu g / \mu g$ & $\mu g / U$ \\
\hline Freshly isolated & $134 \pm 12$ & $4,140 \pm 464$ & $60.03 \pm 5.40$ & $0.032 \pm 0.002$ & $2.2 \pm 0.3$ \\
\hline 3 days & $96 \pm 7 *$ & $753 \pm 32^{\S}$ & $0.42 \pm 0.01^{\S}$ & $0.129 \pm 0.010^{\S}$ & $222.1 \pm 16.0^{\S}$ \\
\hline 9 days & $86 \pm 8^{\ddagger}$ & $394 \pm 24^{\S}$ & $0.04 \pm 0.001^{\S}$ & $0.215 \pm 0.011^{\S} \|$ & $2,121.1 \pm 77.6^{\S \|}$ \\
\hline
\end{tabular}

Values are means \pm SE of 10 independent experiments. In each experiment, porcine NIC aggregates were prepared from three pancreases. Statistical significance of differences was calculated by one-way ANOVA. ${ }^{*} P<0.05,{ }^{\ddagger} P<0.01,{ }^{\S} P<0.0001$ vs. freshly isolated. ${ }^{\|} P<0.0001$ vs. 3 days.

representative aliquots of each preparation were counted, sized, and the final quantity of aggregates was converted to the number equivalent to a diameter of $150 \mu \mathrm{m}$ (35). Aliquots consisting of 1,000 or 2,000 aggregate equivalents were aspirated into polyethylene tubing (PE-50), pelleted by centrifugation, and gently placed under the kidney capsule with the aid of a micromanipulator syringe. Once the tubing was removed, the capsulotomy was cauterized with a disposable high-temperature cautery pen (Aaron Medical Industries, St. Petersburg, FL).

Transplanted mice and normal controls were monitored for blood glucose levels once a week between 8:00 and 11:00 a.m. When the blood glucose level was $\leq 8.4 \mathrm{mmol} / \mathrm{liter}$, the graft was deemed a success. At posttransplantation week 12 , an oral (OGTT) and then an intraperitoneal (IPGTT) glucose tolerance test $48 \mathrm{~h}$ later were performed on NIC recipients with normalized basal glycemia and in normal controls. After a 2-h fast, D-glucose ( $3 \mathrm{mg} / \mathrm{g}$ body wt) was administered as a $50 \%$ solution intragastrically or injected intraperitoneally into nonanesthetized mice. Blood samples were obtained from the tail vein at $0,15,30,60$, and $120 \mathrm{~min}$.

Characterization of harvested NIC grafts. At 14 wk posttransplantation, NIC recipients underwent a nephrectomy of the graft-bearing kidney for morphological analysis or to determine insulin and glucagon contents of the harvested grafts. The grafts in four recipients receiving 2,000 aggregates were, however, not removed at this time, and these animals were monitored for an additional 7 mo. Nephrectomized animals were subsequently monitored to confirm a return of hyperglycemia. The graft-bearing kidneys were immersed in Bouin's solution overnight and embedded in paraffin. Sections, 5- $\mu \mathrm{m}$ thick, were then stained for the presence of insulin- and glucagon-containing cells, as described above. Pieces of native neonatal pig pancreas were also processed and analyzed according to this procedure. In two recipients, the graft and adjacent kidney tissue was fixed in glutaraldehyde then processed for electron microscopy. For hormone extraction, organs were homogenized and then sonicated at $4^{\circ} \mathrm{C}$ in $10 \mathrm{ml}$ of $2 \mathrm{mmol} /$ liter acetic acid $(0.25 \% \mathrm{BSA})$. After 2 -h at $4^{\circ} \mathrm{C}$, tissue homogenates were resonicated, centrifuged $(8,000 \mathrm{~g}, 20 \mathrm{~min})$, then supernatants were collected and the pellets further extracted by sonication in an additional $8 \mathrm{ml}$ of acetic acid. The second supernatant was collected after centrifugation, combined with the first supernatant, total volume was measured, and samples were assayed for insulin and glucagon content. The same procedure was also used to extract hormones from pancreases obtained from NIC recipients, normal control mice, and 1-3-d-old neonatal pigs.

Statistical analysis. Data are expressed as means \pm SE of $n$ independent observations. Statistical significance of differences was calculated with a two-tailed unpaired Student's $t$ test or a one-way ANOVA in case of multiple comparisons.

\section{Results}

Porcine NIC preparation. After collagenase digestion, a mean of $134 \mu \mathrm{g}$ of insulin was recovered per neonatal pancreas (Ta- ble I). The digest contained $\sim 65 \%$ of the total insulin content present in nondigested 1-3-d-old neonatal pig pancreases, which were found to contain $205 \pm 7 \mu \mathrm{g}$ insulin (range $=191-$ $242 \mu \mathrm{g}$; data not shown). Tissue culture resulted in further losses of cellular insulin mass, so that after 3 and $9 \mathrm{~d}$ of culture, 72 and $64 \%$ of the amount initially present in the digest was recovered, respectively (Table I). On the other hand, culture caused a marked reduction in the amount of recoverable DNA, as $<20 \%$ of that found in the digest was present after $3 \mathrm{~d}$ of culture and only $10 \%$ after $9 \mathrm{~d}(P<0.0001$, Table I). Similarly, cultured preparations exhibited amylase values $<1 \%$ of the digests (Table I). The insulin content per microgram of DNA or per amylase content (U) of the porcine NICs significantly increased during culture (Table I). On the basis of the insulin per DNA values, 9 d-cultured NIC preparations were more than sixfold $(P<0.0001)$ enriched in endocrine tissue compared to the freshly isolated material (Table I). When expressed as a ratio of insulin per amylase, enrichment in endocrine tissue was $>900$-fold $(P<0.0001)$ after the 9 -d culture period (Table I).

Electron micrographs of the freshly isolated preparations indicated that $>90 \%$ of the cells were nonendocrine, of which the majority were exocrine $(74 \%)$, and only $7 \%$ were shown to contain secretory vesicles characteristic of endocrine cells (Table II). Immunohistochemical analysis of the digest demonstrated the presence of 5\% insulin-positive and $2 \%$ glucagonpositive cells (Table II). During the first $2 \mathrm{~d}$ of culture, many degenerating cells were observed cleaving away from the edges of a centrally located islet cell aggregate. Microscopically, NIC aggregates developed into spherical structures by the third day of culture and began to exhibit a translucent appearance similar to adult pancreatic islets. Tissue culture markedly reduced the percentage of exocrine cells, so that at $9 \mathrm{~d}$ postisolation $<5 \%$ of the cells were identified as exocrine (Table II). These morphological findings are therefore consistent with the observed reduction in amylase content after culture. The $9 \mathrm{~d}$-cultured preparations consisted of $35 \%$ structurally intact endocrine cells containing well-developed endoplasmic reticulum (Fig. 1). This percentage of endocrine cells was significantly higher than at the start of culture $(P<0.001$; Table II). In general, 9 d-cultured aggregates contained numerous nongranulated epithelial cells (57\%), as well as many duct-like structures (Fig. 1). A low degree of cellular damage was also observed in the electron micrographs (Table II). Immunohistological examination confirmed that $9 \mathrm{~d}$-cultured preparations consisted mainly of epithelial cells with the presence of $24 \%$ insulin-containing and $8 \%$ glucagon-containing cells scattered randomly throughout the aggregate (Fig. $2 \mathrm{C}$ 
Table II. Cellular Composition of Porcine Neonatal Islet Cell Aggregates during Tissue Culture

\begin{tabular}{|c|c|c|c|c|c|c|c|}
\hline \multirow[b]{2}{*}{ Culture period } & \multirow[b]{2}{*}{$n$} & \multicolumn{4}{|c|}{ Cell composition ( $\%$ of total) } & \multicolumn{2}{|c|}{ Cell type (\% positive) } \\
\hline & & Endocrine & Nongranulated & Exocrine & Damaged & Insulin & Glucagon \\
\hline Freshly isolated & 7 & $7 \pm 2$ & $11 \pm 1$ & $74 \pm 2$ & $8 \pm 1$ & $5 \pm 1$ & $2 \pm 1$ \\
\hline 3 days & 5 & $11 \pm 3$ & $45 \pm 3^{*}$ & $41 \pm 3^{*}$ & $4 \pm 1^{\ddagger}$ & $8 \pm 1$ & $3 \pm 1$ \\
\hline 9 days & 7 & $35 \pm 5^{\S \|}$ & $57 \pm 5 *$ पा & $3 \pm 1 * \pi$ & $5 \pm 1$ & $24 \pm 3 * * *$ & $8 \pm 1 * * *$ \\
\hline
\end{tabular}

Values are means \pm SE of $n$ independent determinations. In each experiment, porcine NIC aggregates were prepared from three pancreases. Cell composition was determined in electron micrographs and the percent glucagon and insulin containing cells was determined by immunohistochemistry, as described in Methods. Statistical significance of differences was calculated by one-way ANOVA. ${ }^{\ddagger} P<0.05,{ }^{\S} P<0.001, * P<0.0001$ vs. freshly isolated. ${ }^{\|} P<0.01, * * P<0.001,{ }^{\pi} P<0.0001$ vs. 3 days.

and $D$ ). This random distribution of endocrine cells was also similar to that observed in the native neonatal porcine pancreas (Fig. $2 A$ and $B$ ).

The quantity of aggregates recovered in each experiment was estimated using the method previously described for determining human islet equivalents (35). The mean yield obtained from one neonatal porcine pancreas after collagenase digestion and 9-d culture was 48,526 $\pm 3,125$ aggregates (range $=28,210-90,966$ ). Approximately $50 \%$ of the aggregates measured between 50 and $99 \mu \mathrm{m}, 40 \%$ were $100-149 \mu \mathrm{m}$, and the remainder were either $<50 \mu \mathrm{m}$ or ranged from 150 to $250 \mu \mathrm{m}$.

Insulin secretory responsiveness. The secretory activity of NIC aggregates cultured for $9 \mathrm{~d}$ in the presence or absence of $10 \mathrm{mmol} /$ liter nicotinamide was tested by comparing the percentages of cellular insulin that were released at low glucose ( $2.8 \mathrm{mmol} /$ liter $)$, high glucose $(20 \mathrm{mmol} /$ liter $)$, and high glucose plus theophylline $(10 \mathrm{mmol} /$ liter $)$. No statistically significant differences were noticed in the amounts of insulin secreted at the low glucose concentration (Table III). Incubation in 20 $\mathrm{mmol} /$ liter glucose significantly $(P<0.001)$ increased the secretory rate of both nicotinamide-treated and nontreated NICs; this effect was further potentiated when the NICs were exposed to high glucose plus theophylline (Table III). How- ever, the amount of insulin released and the calculated stimulation indices after incubation with either $20 \mathrm{mmol} / \mathrm{liter}$ glucose or $20 \mathrm{mmol} /$ liter glucose plus $10 \mathrm{mmol} /$ liter theophylline were significantly higher when the NICs were previously cultured with nicotinamide. Nicotinamide-treated aggregates exhibited stimulation indices greater than fivefold when comparing insulin release at high glucose versus that at low glucose. When exposed to $20 \mathrm{mmol} /$ liter glucose in combination with 10 $\mathrm{mmol} /$ liter theophylline, stimulation indices were $>39$-fold (Table III). Analysis of the total cellular insulin and DNA content recovered per NIC aggregate and the percentage of insulin-positive cells revealed no significant differences between nicotinamide-treated and untreated preparations (data not shown).

Composition of NIC grafts. Before transplantation, the composition of $9 \mathrm{~d}$-cultured NIC grafts was determined by electron microscopy, immunohistochemistry, hormone content, and DNA assay (Tables II and IV). As previously described, the NIC grafts were composed of $57 \%$ nongranulated and $35 \%$ endocrine cells; the remaining cell types were identified as either exocrine (3\%) or damaged cells (5\%; Table II). Immunohistochemical staining for insulin and glucagon was positive for 24 and $8 \%$ of the total cell population, respectively

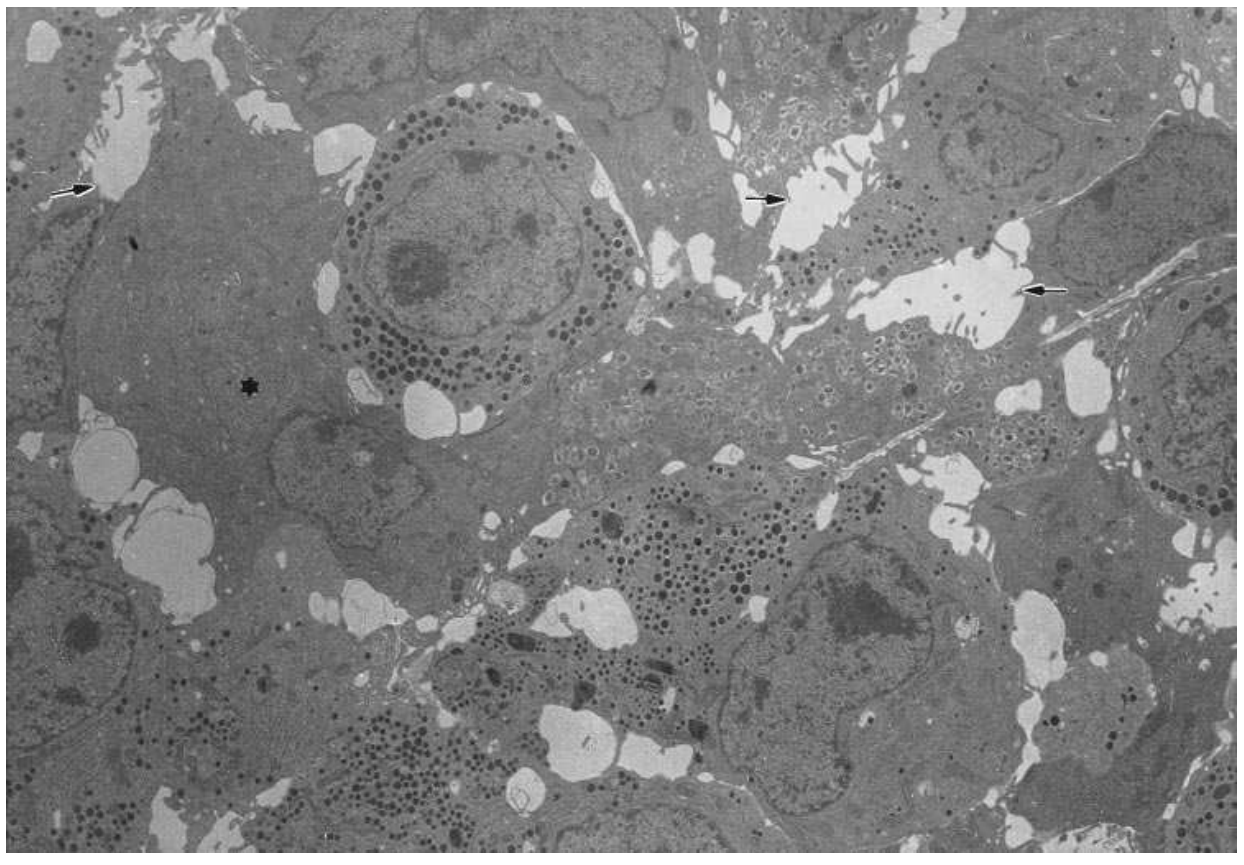

Figure 1. Electron micrograph of porcine NIC aggregates after nine days culture. Beta cells appear well granulated, structurally intact, and contain secretory granules which conform to adult granule morphology. The aggregate also contains nongranulated cells (star) and numerous duct-like structures (arrows) $(\times 1,300)$. 

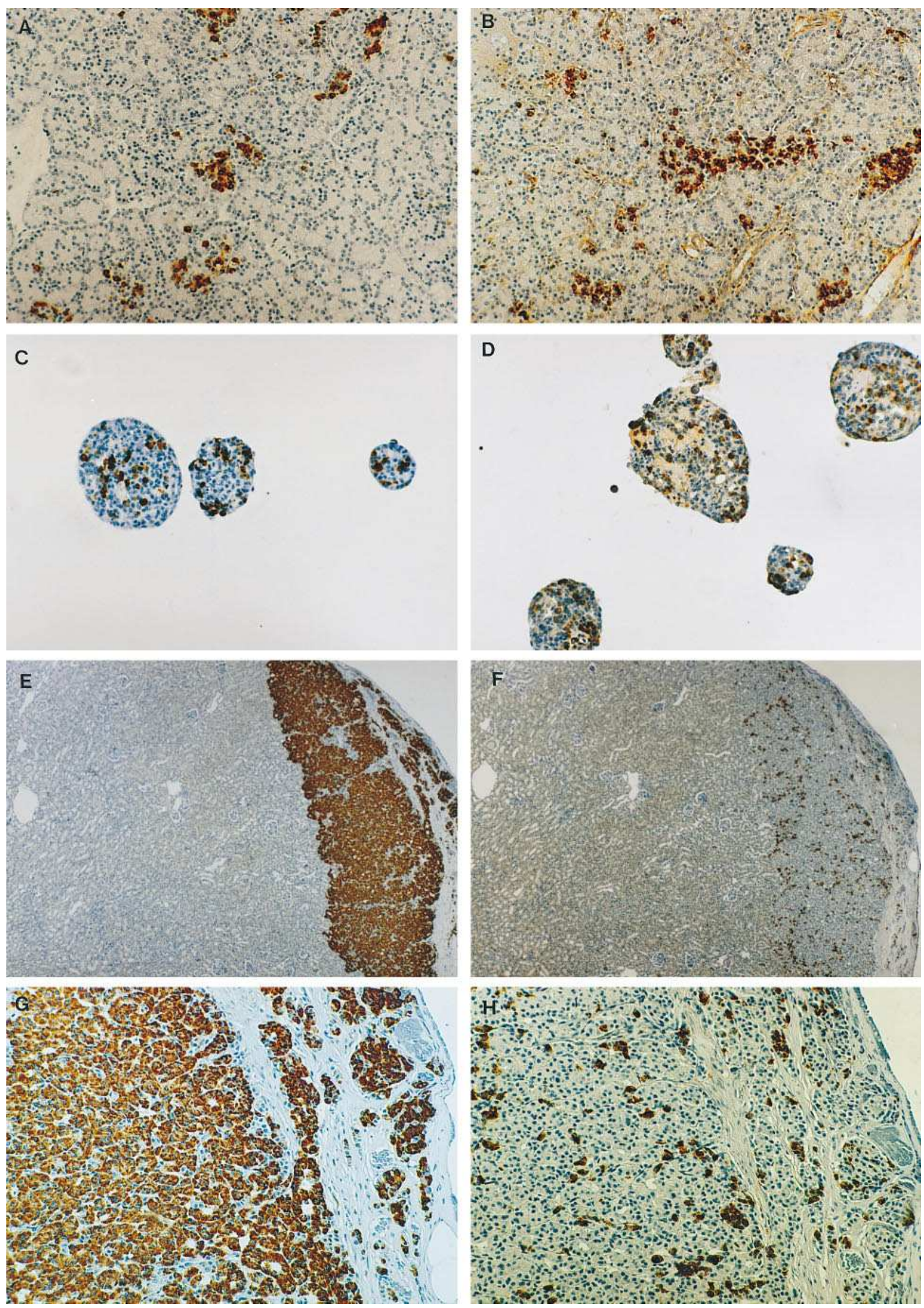

Figure 2. Light micrographs of native neonatal (1-3 d old) porcine pancreas $(A$ and $B, \times 250), 9 \mathrm{~d}$-cultured NIC aggregates $(C$ and $D, \times 250)$, and porcine NIC aggregates $14 \mathrm{wk}$ after transplantation beneath the kidney capsule of alloxan diabetic nude mice $(E$ and $F, \times 125 ; \mathrm{G}$ and $\mathrm{H}$, $\times 250)$. Sections were counterstained with Harris's hemotoxylin then immunohistochemically stained for insulin $(A, C, E$, and $G)$ or glucagon $(B$, $D, F$, and $H$ ). 
Table III. Effect of Nicotinamide on Insulin Secretory Capacity of Porcine Neonatal Islet Cell Aggregates after $9 \mathrm{~d}$ of Culture

\begin{tabular}{|c|c|c|c|c|c|c|}
\hline \multirow[b]{2}{*}{ Condition } & \multirow[b]{2}{*}{$n$} & \multicolumn{3}{|c|}{ Isolated islet fraction (insulin secretory activity [\% content]) } & \multicolumn{2}{|c|}{ Stimulation indices } \\
\hline & & $2.8 \mathrm{mmol} /$ /iter glucose & $20 \mathrm{mmol} /$ /iter glucose & $\begin{array}{l}20 \mathrm{mmol} / \text { /iter glucose }+ \\
10 \mathrm{mmol} / \text { liter theophylline }\end{array}$ & High:low & $\begin{array}{c}\text { High }+ \\
\text { theophylline:low }\end{array}$ \\
\hline \multicolumn{7}{|l|}{ Ham's F10 } \\
\hline Nicotinamide & 10 & $0.9 \pm 0.1$ & $4.8 \pm 0.5$ & $34.3 \pm 2.9$ & $5.5 \pm 0.6$ & $39.9 \pm 4.7$ \\
\hline No nicotinamide & 4 & $1.1 \pm 0.2$ & $2.4 \pm 0.6^{*}$ & $18.1 \pm 3.5^{\ddagger}$ & $2.4 \pm 0.9^{*}$ & $19.7 \pm 4.0^{*}$ \\
\hline
\end{tabular}

Values are means \pm SE of $n$ independent experiments. In each experiment, porcine NIC aggregates were prepared from three pancreases and cultured for $9 \mathrm{~d}$ in the presence or absence of $10 \mathrm{mmol} /$ liter nicotinamide. Stimulation indices were calculated by dividing the amount of insulin released at high glucose $(20 \mathrm{mmol} /$ liter $)$ or high glucose plus $10 \mathrm{mmol} /$ liter theophylline by that released at low glucose $(2.8 \mathrm{mmol} /$ liter $)$. Statistical significance of differences was calculated with unpaired Student's $t$ test (2-tailed). ${ }^{*} P<0.05,{ }^{\ddagger} P<0.01$ vs. Ham's F10 plus 10 mmol/liter nicotinamide.

(Table II). On the basis of the implants' DNA content (Table IV) and the observation that single porcine neonatal islet cells prepared from $9 \mathrm{~d}$-cultured aggregates were found to contain $7.1 \mathrm{pg}$ DNA/cell (data not shown), it was calculated that grafts consisting of 1,000 or 2,000 aggregates contained 1.3 or 2.6 million cells, respectively. In view of the percentage of insulinpositive cells, the implants should therefore contain $\sim 0.3$ or $0.6 \times 10^{6}$ insulin-producing $\beta$ cells. The measurement of DNA, insulin, and glucagon content also confirmed that the mass of the 2,000 aggregate grafts was correspondingly larger than the 1,000 aggregate grafts.

Transplantation of NIC aggregates into diabetic nude mice. After alloxan administration, all NIC recipients exhibited blood glucose levels above $20 \mathrm{mmol} /$ liter. Diabetic controls $(n=9)$ not receiving a graft were shown to survive for $11 \pm 4 \mathrm{~d}$. All animals transplanted with 2,000 NIC aggregates exhibited blood glucose values $\leq 8.4 \mathrm{mmol} /$ liter within $8 \mathrm{wk}$ posttransplantation (Table V). This metabolic state was maintained over the 14 wk follow-up period, and in four animals which were not killed at $14 \mathrm{wk}$, normoglycemia was maintained for $>11$ mo posttransplantation (data not shown). On the other hand, 10 of the 13 animals implanted with 1,000 aggregates achieved normoglycemia (blood glucose $\leq 8.4 \mathrm{mmol} / \mathrm{liter}$ ) within the follow-up period (Table V). At 14 wk posttransplantation, blood glucose values of those 1,000 aggregate recipients not obtaining euglycemia were: $10.7,12.2$, and 14.4 $\mathrm{mmol} /$ liter. Comparison with normal controls indicated that recipients of 2,000 NIC aggregates exhibited significantly lower blood glucose levels at weeks 12 and 14 (Table V). These values did not, however, continue to decrease further, as those recipients $(n=4)$ allowed to survive long term exhibited glucose levels of $5.2 \pm 0.6$ at 11 mo posttransplantation $(P<$ 0.01 vs. normal controls; data not shown). No differences were measured between the mean glucose values of the 10 normoglycemic 1,000-aggregate recipients and normal controls (Table V). In both transplanted groups, removal of the graft- bearing kidney for morphological examination or hormone extraction was followed by a rapid return to the diabetic state, indicating that the NIC grafts were responsible for the normoglycemic state.

Glucose tolerance tests were performed on normoglycemic mice $12 \mathrm{wk}$ posttransplantation, and when compared to normal control mice, recipients of 2,000 aggregates exhibited significantly lower glycemic values at all time points (Fig. 3). When the 1,000-aggregate recipients were compared to normal controls, their blood glucose levels were not statistically different throughout both tests. Comparison of the two transplant groups indicated that the 1,000-aggregate recipients exhibited statistically higher values at 15 and $30 \mathrm{~min}$ in the OGTT and at 15, 30, and $60 \mathrm{~min}$ for the IPGTT (Fig. 3). In all groups, the glycemia at min 120 after the bolus of glucose was not significantly different from the values at min 0 .

Hormone content and morphological characterization of NIC grafts. Before implantation, NIC grafts contained on average $1.9 \mu \mathrm{g}$ of insulin/1,000 aggregates or $4.0 \mu \mathrm{g}$ of insulin/ 2,000 aggregates (Table IV). 14 wk posttransplantation, considerably larger quantities of cellular insulin were recovered from the graft-bearing kidneys (Table VI). There was, however, no difference in the glucagon content between the harvested grafts and the grafts analyzed at the time of implantation (Table VI). The insulin content of grafts obtained from normoglycemic recipients implanted with 1,000 aggregates contained 30 -fold $(63.7 \mu \mathrm{g})$ more insulin than what was initially transplanted (Table VI). Grafts retrieved from animals receiving 1,000 aggregates and which did not achieve euglycemia were shown to contain $12.2,16.7$, and $18.9 \mu \mathrm{g}$ insulin (data not shown). In animals transplanted with 2,000 aggregates, grafts contained $>20$-fold $(88 \mu \mathrm{g})$ more insulin than at the time of implantation (Table VI). The amount of insulin extracted from grafts obtained from recipients of 1,000 and 2,000 aggregates corresponds to, respectively, $>74$ and $141 \%$ of the pancreatic insulin content in age-matched normal control mice

Table IV. Composition of Porcine Neonatal Islet Cell Grafts before Transplantation

\begin{tabular}{|c|c|c|c|c|c|}
\hline \multirow[b]{2}{*}{ Graft } & \multicolumn{3}{|c|}{ Content ( $\mu \mathrm{g} / \mathrm{graft})$} & \multicolumn{2}{|c|}{ Purity $(\mu \mathrm{g} / \mu \mathrm{g})$} \\
\hline & Insulin & Glucagon & DNA & Insulin/DNA & Glucagon/DNA \\
\hline 1,000 NIC aggregates & $1.9 \pm 0.3$ & $0.62 \pm 0.05$ & $8.9 \pm 0.7$ & $0.213 \pm 0.022$ & $0.073 \pm 0.008$ \\
\hline 2,000 NIC aggregates & $4.0 \pm 0.4$ & $1.32 \pm 0.11$ & $18.9 \pm 1.5$ & $0.219 \pm 0.025$ & $0.072 \pm 0.007$ \\
\hline
\end{tabular}

Values are means \pm SE of 10 independent experiments. In each experiment, porcine NIC aggregates were prepared from three pancreases. 


\begin{tabular}{|c|c|c|c|c|c|c|c|c|}
\hline \multirow[b]{2}{*}{ Experimental groups } & \multirow[b]{2}{*}{$n$} & \multicolumn{7}{|c|}{ Weeks posttransplantation } \\
\hline & & 2 & 4 & 6 & 8 & 10 & 12 & 14 \\
\hline \multicolumn{9}{|c|}{ Normoglycemic animals*/Total number of recipients } \\
\hline \multicolumn{9}{|l|}{ Recipients } \\
\hline 1,000 NIC's & 13 & $0 / 13$ & $2 / 13$ & $5 / 13$ & $8 / 13$ & $10 / 13$ & $10 / 13$ & $10 / 13$ \\
\hline 2,000 NIC's & 20 & $4 / 20$ & $6 / 20$ & $13 / 20$ & $20 / 20$ & $20 / 20$ & $20 / 20$ & $20 / 20$ \\
\hline \multicolumn{9}{|c|}{ Mean blood glucose (mmol/liter) } \\
\hline \multicolumn{9}{|l|}{ Recipients } \\
\hline 1,000 NIC's & 13 & $23.8 \pm 0.6^{\ddagger}$ & $20.5 \pm 1.6^{\ddagger}$ & $14.8 \pm 1.7^{\S}$ & $11.8 \pm 1.5^{\|}$ & $9.5 \pm 1.3$ & $8.3 \pm 1.1$ & $7.0 \pm 0.9$ \\
\hline 1,000 NIC's st & 10 & $23.7 \pm 0.5^{\ddagger}$ & $19.5 \pm 1.9^{\ddagger}$ & $12.7 \pm 1.6$ & $9.5 \pm 1.3$ & $7.0 \pm 0.2$ & $6.3 \pm 0.3$ & $5.3 \pm 0.2$ \\
\hline 2,000 NIC's & 20 & $18.7 \pm 1.5^{\ddagger}$ & $14.4 \pm 1.3^{\|}$ & $9.1 \pm 0.8$ & $7.1 \pm 0.3$ & $4.9 \pm 0.2$ & $4.1 \pm 0.1^{\|}$ & $4.2 \pm 0.1^{\S}$ \\
\hline Normal Controls & 9 & $6.8 \pm 0.3$ & $6.9 \pm 0.3$ & $7.1 \pm 0.6$ & $7.1 \pm 0.3$ & $7.3 \pm 0.3$ & $6.7 \pm 0.3$ & $6.9 \pm 0.2$ \\
\hline
\end{tabular}

Values are means \pm SE of $n$ recipients. *Normoglycemia defined as blood glucose values $\leq 8.4 \mathrm{mmol} /$ liter. "Data represents means of only those recipients obtaining normoglycemia. Statistical significance of differences was calculated by one-way ANOVA. $\| P<0.05,{ }^{\S} P<0.01,{ }^{\ddagger} P<0.0001$ vs. normal control group.

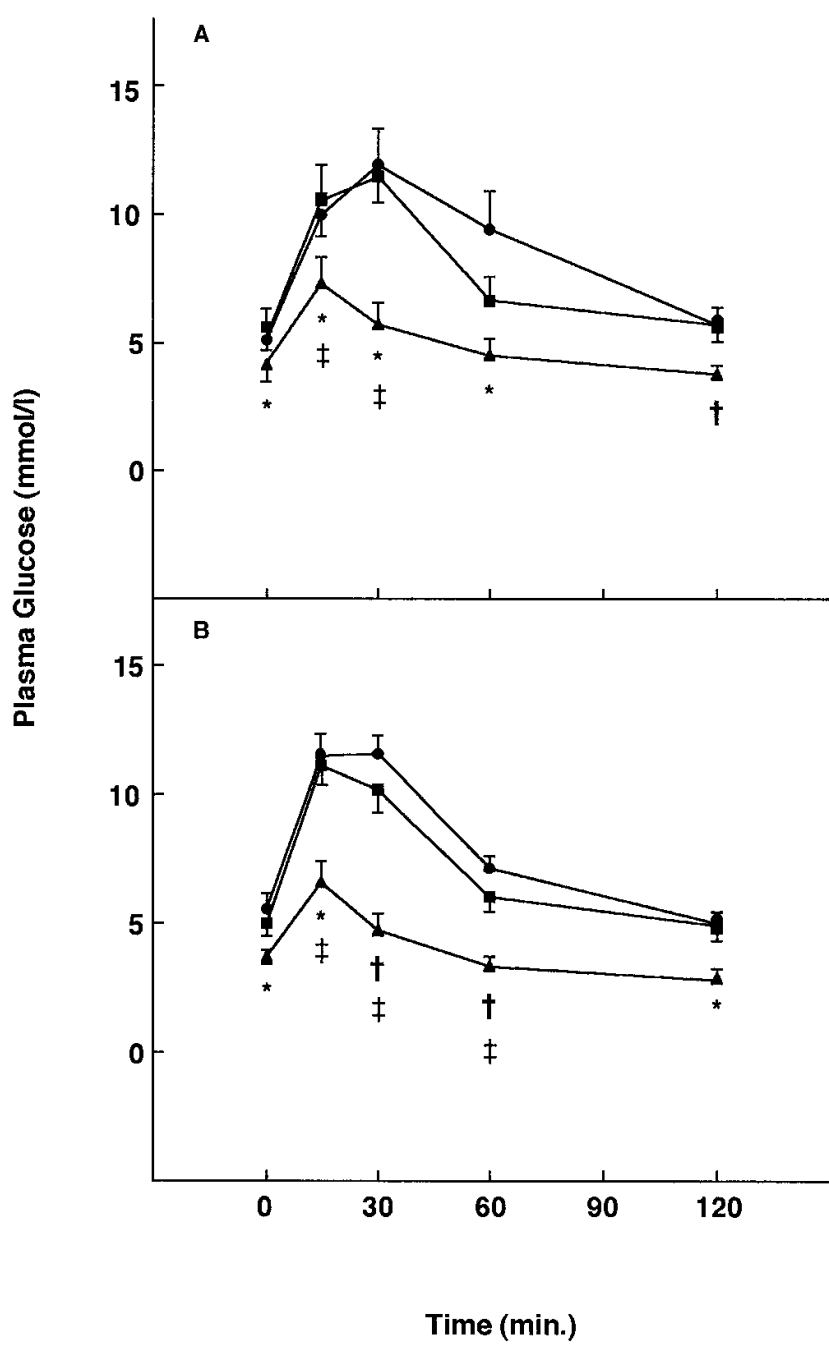

Figure 3. Blood glucose values during oral $(A$; OGTT) and intraperitoneal $(B$; IPGTT) administration of glucose to nude mice transplanted with $1,000(\mathbf{\square} ; n=10)$ or $2,000(\mathbf{\Lambda} ; n=12)$ porcine NIC ag-
(Table VI). Glucagon content, on the other hand, was similar to that found in pancreases of normal controls. The recipients' pancreatic insulin content was $<1 \%$ of that contained in normal control animals, whereas their glucagon content was similar to that in normal controls (Table VI).

Macroscopically, considerable growth of the NIC grafts was evident after $14 \mathrm{wk}$ posttransplantation. Immunohistological examination of the grafts revealed a highly vascularized tissue, consisting predominantly of well-granulated insulin- and glucagon-containing cells (Fig. $2 E \& G$ and $F \& H$, respectively). Epithelial cells were not frequently seen in the grafts. The $\beta$ cells, which composed the major volume of the graft, were arranged in ductal-tubular-like structures and the endocrine non- $\beta$ cells were scattered randomly among the $\beta$ cells. No marked differences in morphology were observed between the two transplant groups. In electron micrographs, donor endocrine cells were shown to be structurally intact, highly granulated, and mitotic activity was detected within some of the grafts' $\beta$ cells (Fig. 4).

\section{Discussion}

The present data indicate that viable porcine neonatal islet cells can be successfully isolated in large numbers by culturing collagenase digested pancreas for $9 \mathrm{~d}$. Since we and others (36) observed that the endocrine portion of the neonatal pig pancreas does not contain intact and mature islets, but rather exhibits a random distribution of endocrine cells, no attempts were made to process these organs using methods conventionally used for isolating adult mammalian islets. Neonatal pig pancreases were therefore digested according to a modification of the method of Korsgren et al. (10) for preparing fetal pig islet cell clusters. Tissue culture was then used to enrich the preparations in endocrine cells before assessing their viability

gregates in comparison to age-matched normal control mice $(\bullet ; n=$ 9). ${ }^{\circledR} P<0.05 ;{ }^{\dagger} P<0.01$ vs. normal controls; ${ }^{\ddagger} P<0.05$ vs. 1,000 aggregate recipients. 


\begin{tabular}{lccc}
\hline & & & Hormone content $(\mu \mathrm{g} /$ organ $)$ \\
\cline { 4 - 4 } \multicolumn{1}{c}{ Experimental group } & $n$ & Insulin & Glucagon \\
\hline $\begin{array}{l}\text { Normal controls } \\
\quad \text { pancreas }\end{array}$ & 9 & $36.5 \pm 1.3$ & $0.53 \pm 0.02$ \\
$\begin{array}{l}\text { Recipients of 1,000 NIC aggregates } \\
\text { pancreas }\end{array}$ & 8 & $<0.7$ & $0.51 \pm 0.03$ \\
$\quad$ kidney & 8 & $63.7 \pm 9.2^{*}$ & $0.40 \pm 0.07$ \\
$\begin{array}{l}\text { Recipients of 2,000 NIC aggregates } \\
\text { pancreas } \\
\text { kidney }\end{array}$ & 14 & $<0.7$ & $0.46 \pm 0.06$ \\
& 14 & $88.0 \pm 5.6^{\ddagger \S}$ & $0.47 \pm 0.05$ \\
\hline
\end{tabular}

Values are means \pm SE for $n$ animals. All recipients exhibited normal glycemia and were analyzed at 14 wk posttransplantation. Statistical significance of differences was calculated by one-way ANOVA. ${ }^{*} P<0.05,{ }^{\star} P<0.0001$ vs. normal control pancreas. ${ }^{\S} P<0.05$ vs. kidney grafts in recipients of 1,000 NIC aggregates.

through an in vitro stimulation assay and by transplantation into diabetic nude mice. Selection of the media supplements was based on the following considerations: (a) serum was omitted due to its ability to promote the survival of contaminating fibroblasts and pancreatic exocrine cells (unpublished observations), and based on previous reports $(37,38)$, albumin was selected as a serum substitute; (b) IBMX was used for its capacity to stimulate DNA synthesis in rat islets (39), and its potential to enhance survival of cultured rat $\beta$ cells (38); (c) 10 $\mathrm{mmol} /$ liter glucose was added to enhance $\beta$ cell replication (40, 41) and for its cytoprotective effect during culture of purified rat $\beta$ cells (38); and ( $d$ ) nicotinamide was included due to its ability to stimulate islet cell DNA replication (42), and its beneficial effect on the metabolic function of porcine fetal islet cells (12).

Using insulin content as a parameter, $\sim 65 \%$ of the initial pancreatic $\beta$ cell mass was recovered after the collagenase di- gestion phase. This index of $\beta$ cell recovery is likely an underestimation because it does not take into account possible degranulation which could occur during the digestion. A 9-d culture of the digest succeeded in eliminating the majority of contaminating exocrine cells and resulted in the formation of numerous islet cell aggregates. The NIC aggregates were predominantly composed of epithelial cells, exhibited a purity of $35 \%$ endocrine cells, and contained $\sim 25 \%$ insulin-positive cells. With the technique used in this study, generally 50,000 NIC aggregates were recovered from one pancreas. These yields are significantly higher than those obtained in studies using mid-gestational fetal pigs, where the average yield per fetus was $\sim 10,000$ islet cell clusters $(10,13)$. These differences in yield are likely due to the greater pancreatic mass in neonatal pigs.

When considering the mean DNA recovery per pancreas, the DNA content of porcine neonatal islet cells $(7.1 \mathrm{pg} / \mathrm{cell})$,

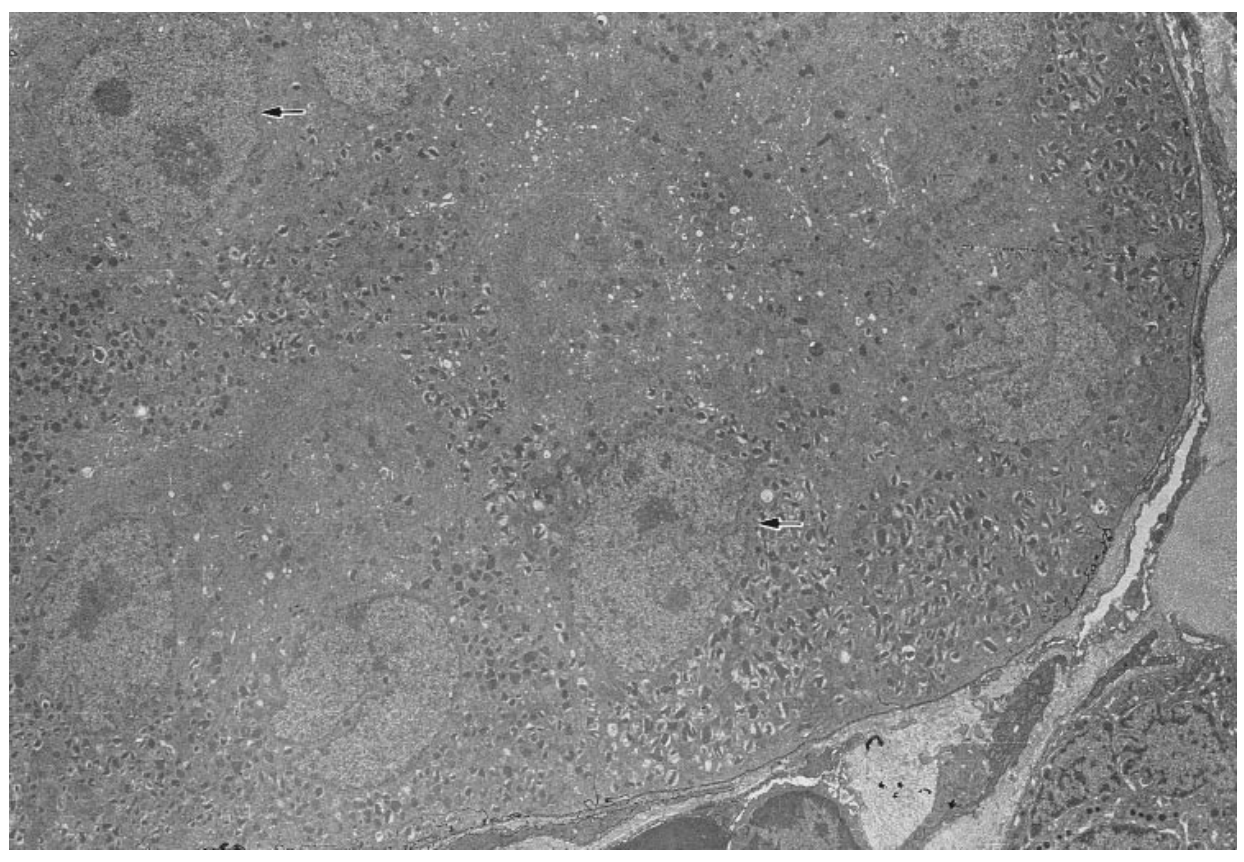

Figure 4. Electron microscopy of porcine NIC aggregates 14 wk after transplantation beneath the kidney capsule of alloxan diabetic nude mice. $\beta$ cells are structurally intact, highly granulated and contain well developed endoplasmic reticulum; some cells are shown to express mitotic figures (arrows, $\times 6,200)$. 
and the percentage of insulin-positive cells, the following equation can be used to calculate total $\beta$ cell mass in the isolated NIC aggregates:

\section{$\frac{\text { Total DNA content }}{7.1 \mathrm{pg} \text { DNA/NIC }} \times \frac{\% \text { insulin positive cells }}{100}=$ \\ number of $\beta$ cells recovered per pancreas}

The number of $\beta$ cells recovered from freshly isolated, $3 \mathrm{~d}$-, and $9 \mathrm{~d}$-cultured preparations is calculated to be $29.2,8.5$, and 13.3 million cells per pancreas, respectively. Similarly, when considering the percentage of $\alpha$ cells the calculated number of $\alpha$ cells is $11.7,3.2$, and 4.4 million cells per pancreas, respectively. The decrease in endocrine cell mass between the isolation and 3-d culture is likely the result of deleterious effects of the collagenase digestion and the presence of potentially cytotoxic proteases released from degenerating exocrine cells during culture. In contrast, the increase in both $\alpha$ and $\beta$ cell mass (i.e., 38 and $56 \%$, respectively) between day 3 and day 9 of culture, can possibly be explained by the growth or differentiation of new endocrine cells. Cellular insulin content also decreased significantly during the first $3 \mathrm{~d}$ of culture, and this is presumably related to the fall in $\beta$ cell mass. However, between days 3 and 9 of culture, cellular insulin content decreased by $10 \%$, yet $\beta$ cell mass was shown to increase. Thus, even though new $\beta$ cells were forming and contributing to the total insulin pool, their insulin stores as well as those of preexisting $\beta$ cells likely decreased as a result of secretory activity that exceeds the rate of insulin biosynthesis during culture. The recovery of cellular DNA decreased throughout the 9-d culture period, which is likely the result of the marked elimination of contaminating exocrine cells.

Many studies have indicated that the fetal $\beta$ cell has a poor insulin response to glucose, which is rapidly converted to a more adult pattern after birth (22-25). In the present study, porcine neonatal $\beta$ cells were capable of secreting significant amounts of insulin in response to a glucose challenge. This secretory capacity was further augmented when the NIC aggregates were challenged with glucose plus theophylline, or when they were precultured in the presence of nicotinamide. These results are comparable to those described for islet cells prepared from the neonatal pig pancreas (1-3 d old) after trypsin dissociation and 7-d culture (27) and are significantly higher than those observed for fetal pig islet cells $(10,12)$; suggesting that in the pig, neonatal $\beta$ cells are more responsive to glucose than fetal $\beta$ cells. A possible explanation for nicotinamide's beneficial effect is that it may act as a protective agent, thereby preserving the insulin secretory activity of the neonatal $\beta$ cell throughout the culture period. Nicotinamide has been shown to protect against the cytotoxic action of streptozotocin on $\beta$ cells $(43,44)$ and to slow or arrest the development of diabetes in the nonobese diabetic mice (45). The agent may therefore enhance survival of porcine NICs after collagenase digestion and protect them from chemical disruption due to the proteolytic activity of enzymes leaking from degenerating exocrine cells during culture. Interestingly, culture in nicotinamide did not increase the frequency of insulin-positive cells in the NIC aggregates. This observation is in contrast to that observed when fetal porcine (12) and human (46) islet cell clusters were cultured with nicotinamide.

Diabetic nude mice were transplanted with 1,000 or 2,000 NIC aggregates, containing either 3 or $6 \times 10^{5} \beta$ cells. At post- transplantation wk $14,75 \%$ of the mice receiving 1,000 aggregates exhibited blood glucose values $\leq 8.4 \mathrm{mmol} / \mathrm{liter}$, whereas, 2,000 aggregates cured diabetes in $100 \%$ of the animals within $8 \mathrm{wk}$ after implantation. In contrast, Davilli and associates demonstrated that 2,000 adult porcine islet equivalents infrequently produced normoglycemia in diabetic nude mice, and that 4,000 islet equivalents with an average cellular insulin mass of $38.4 \mu \mathrm{g}$ required $>5 \mathrm{wk}$ to normalize diabetic nude mice (15). In the present study, only 2,000 porcine NIC aggregates containing $4 \mu \mathrm{g}$ insulin were required to achieve euglycemia long term. One possible explanation for these differences is that adult porcine islets are considerably more fragile than the NIC aggregates and this may result in significantly more $\beta$ cell death and malfunction of the adult islets posttransplantation. It is also conceivable that during the initial days after implantation, reduction in the grafts' $\beta$ cell mass may occur due to poor vascularization and anoxic conditions. Thus, with adult islet grafts the final $\beta$ cell mass that becomes functionally active after the engraftment period may be considerably less than the amount initially implanted. On the other hand, the ability of immature NICs to differentiate and proliferate may potentially allow them to replace any $\beta$ cell mass lost to ischemic damage in the immediate posttransplantation period.

Although the NIC grafts were unable to correct diabetes immediately after transplantation, they eventually developed the capacity to establish and maintain euglycemia, likely because the relatively few $\beta$ cells implanted initially were subsequently supplemented by the growth and/or differentiation of additional new $\beta$ cells. Interestingly, all recipients survived this hyperglycemic period, yet diabetic controls survived for only $11 \pm 4 \mathrm{~d}$ after alloxan treatment, suggesting that even in the first 2 wk posttransplantation, NIC grafts produced sufficient insulin to keep recipients alive, although not euglycemic. We hypothesize that a hyperglycemic environment may be essential to inducing the growth and differentiation of new $\beta$ cells in our experimental model, and perhaps also in the clinical setting. At the time of implantation, the insulin content of NIC grafts corresponded to only $5-10 \%$ of the pancreatic insulin content found in aged-matched normal controls. After transplantation, the grafts' insulin mass increased by $>20$-fold. Whether this increase in insulin mass was related to the birth of new $\beta$ cells through differentiation of epithelial cells in the NIC aggregates and/or replication of existing $\beta$ cells was not assessed in this study. It has however been suggested that the major source of newly formed $\beta$ cells in transplanted porcine islet cell clusters is from undifferentiated epithelial cells rather than from preexisting $\beta$ cells (11). Our morphological data indirectly support this concept, since at the time of implantation NIC grafts were composed predominantly of epithelial cells, whereas several weeks after transplantation, few epithelial cells were detected and insulin-producing $\beta$ cells now comprised the major volume of the graft. It cannot be excluded, however, that $\beta$ cell proliferation did not contribute to at least some of the increased insulin content of the grafts, as electron micrographs indicated mitotic activity within some of the engrafted $\beta$ cells. The use of semiquantitative morphometric techniques, such as bromodeoxyuridine labeling and simultaneous immunostaining for islet hormones (15), should provide further insight into the growth kinetics of porcine NIC grafts. It is worthy to note that the grafts' glucagon content did not increase after transplantation, suggesting that no additional growth of $\alpha$ cells occurred. Similarly, in studies where fetal 
porcine islet cells were implanted into alloxan-diabetic nude mice, the frequency of glucagon-containing cells markedly decreased after transplantation (11). These observations indicate that in immature islet cell grafts, continued growth and differentiation of endocrine non- $\beta$ cells is limited, if not inhibited, when transplanted under the kidney capsule of alloxan-diabetic nude mice.

The pancreases of normal control mice were shown to contain $\sim 40 \mu \mathrm{g}$ insulin and grafts obtained from recipients of 2,000 NIC aggregates contained $88 \mu \mathrm{g}$ insulin. The apparent excess $\beta$ cell mass in these animals could explain their lower blood glucose levels when compared to age-matched normal controls. On the other hand, this phenomenon has also been observed in nude mice transplanted with adult porcine islets in which the grafts' $\beta$ cell mass did not differ from that found in the pancreas of normal control mice (15). Thus, an alternative explanation for this observation is that the donor's $\beta$ cells eventually regulated the recipient's glucose homeostasis to that found in pigs, rather than in mice. Therefore, since plasma glucose levels in pigs and humans are similar, these results indicate that transplantation of porcine NICs into humans should theoretically maintain blood sugars within the recipient's physiological range.

In conclusion, the neonatal porcine pancreas can be used for the isolation of a large number of functionally viable islet cells. Furthermore, due to their ready availability and inherent capacity to proliferate and differentiate both in vitro and in vivo, they constitute an attractive source of insulin-producing tissue for studies of islet cell neogenesis or as a source of xenogeneic islet cells for clinical transplantation. However, before this tissue can be considered for application in humans many questions need to be addressed, in light of the work of Groth et al. (13), which showed that when fetal porcine islet cells were transplanted into type I diabetics there was no evidence to indicate engraftment of these cells.

\section{Acknowledgments}

The authors thank Dr. Ming Chen for his help with the electron microscopic studies, Joyce Sproul for assistance with immunohistochemistry, Debra Dixon and Carl Bengston for technical assistance, and Dr. Alex Rabinovitch for helpful discussions.

Support was provided by the MacLachlan Fund of the University of Alberta Hospitals, The Medical Research Council of Canada, and a Diabetes Interdisciplinary Research Program grant from the Juvenile Diabetes Foundation International. G.S. Korbutt is a recipient of a Canadian Diabetes Association Postdoctoral Fellowship Award.

\section{References}

1. Scharp, D.W., P.E. Lacy, J.V. Santiago, C.S. McCullough, L.G. Weide, L. Falqui, P. Marchetti, R.L. Gingerich, A.S. Jaffe, P.E. Cryer, C.B. Anderson, and M.W. Flye. 1990. Insulin independence after islet transplantation into type 1 diabetic patient. Diabetes. 39:515-518.

2. Warnock, G.L., N.M. Kneteman, E. Ryan, R.E.A. Seelis, A. Rabinovitch, and R.V. Rajotte. 1991. Normoglycemia after transplantation of freshly isolated and cryopreserved pancreatic islets in type 1 (insulin-dependent) diabetes mellitus. Diabetologia. 34:55-58.

3. Socci, C., L. Falqui, A.M. Davalli, C. Ricordi, S. Braghi, F. Bertuzzi, P. Maffi, A. Secchi, F. Gavazzi, M. Freschi, et al. 1991. Fresh human islet transplantation to replace pancreatic endocrine function in type 1 diabetic patients. Acta Diabetol. 28:151-157.

4. Warnock, G.L., N.M. Kneteman, E. Ryan, A. Rabinovitch, and R.V. Rajotte. 1992. Long-term follow-up after transplantation of insulin-producing pancreatic islets into patients with type 1 (insulin-dependent) diabetes mellitus. $\mathrm{Di}$ abetologia. 35:89-95.
5. Ricordi, C., A.G. Tzakis, P.B. Carroll, Y. Zeng, H.L. Rodriguez Rilo, R. Alejandro, R. Shapiro, J.J. Fung, A.J. Demetris, D.H. Mintz, and T.E. Starzl. 1992. Human islet isolation and allotransplantation in 22 consecutive cases. Transplantation (Baltimore). 53:407-414.

6. Alejandro, R., S. Strasser, V. Esquenazi, G. Burke, J. Nevry, J. Miller, E.T. Shapiro, C. Ricordi, and D. Mintz. 1994. Long-term survival of intraportal islet allografts in type 1 diabetes mellitus. In Pancreatic Islet Cell Transplantation. C. Ricordi, editor. RG Landes Co., Austin, TX. 410-413.

7. Gray, D.W.R., P. McShane, A. Grant, and P.J. Morris. 1984. A method for isolation of islets of Langerhans from the human pancreas. Diabetes. 33: 1055-1061.

8. Warnock, G.L., D.K. Ellis, R.V. Rajotte, I. Dawidson, S. Baekkeskov, and J. Egebjerg. 1988. Studies of the isolation and viability of human islets of Langerhans. Transplantation (Baltimore). 45:957-963.

9. Ricordi, C., P.E. Lacy, E.H. Finke, B.J. Olack, and D.W. Scharp. 1988. Automated method for isolation of human pancreatic islets. Diabetes. 37:413420 .

10. Korsgren, O., S. Sandler, A.S. Landström, L. Jansson, and A. Andersson. 1988. Large-scale production of fetal porcine pancreatic isletlike cell clusters. An experimental tool for studies of islet cell differentiation and xenotransplantation. Transplantation (Baltimore). 45:509-514.

11. Korsgren, O., L. Jansson, D. Eizirik, and A. Andersson. 1991. Functional and morphological differentiation of fetal porcine islet-like clusters after transplantation into nude mice. Diabetologia. 34:379-386.

12. Korsgren, O., A. Andersson, and S. Sandler. 1993. Pretreatment of fetal porcine pancreas in culture with nicotinamide accelerates reversal of diabetes after transplantation to nude mice. Surgery (St. Louis). 113:205-214.

13. Groth, C.G., O. Korsgren, A. Tibell, J. Tollemar, E. Möller, J. Bolinder, J. Ostman, F.P. Reinholt, C. Hellerström, and A. Andersson. 1994. Transplantation of porcine fetal pancreas to diabetic patients. Lancet. 344:1402-1404.

14. Liu, X., K.F. Federlin, R.G. Bretzel, B.J. Hering, and M.D. Brendal. 1991. Persistent reversal of diabetes by transplantation of fetal pig proislets into nude mice. Diabetes. 40:858-866.

15. Davalli, A.M., Y. Ogawa, L. Scaglia, Y. Wu, J. Hollister, S. BonnerWeir, and G.C. Weir. 1995. Function, mass, and replication of porcine and rat islets transplanted into diabetic nude mice. Diabetes. 44:104-111.

16. Marchetti, P., R. Giannarelli, S. Cosimi, P. Masiello, A. Coppelli, P. Viacava, and R. Navalesi. 1995. Massive isolation, morphological and functional characterization, and xenotransplantation of bovine pancreatic islets. Diabetes. 44:375-381.

17. Ricordi, C., C. Socci, A.M. Davalli, C. Staudacher, P. Baro, A. Vertova, I. Sassi, F. Gavazzi, G. Pozza, and V. Di Carlo. 1989. Isolation of the elusive pig islet. Surgery (St. Louis). 107:688-694.

18. Socci, C., C. Ricordi, A.M. Davalli, C. Staudacher, P. Baro, A. Vertova, M. Freschi, F. Gavazzi, S. Braghi, G. Pozza, and V. Di Carlo. 1989. Selection of donors significantly improves pig islet isolation yield. Horm. Metab. Res. 25(Suppl. 1):32-35.

19. Kirchhof, N., B.J. Hering, V. Geiss, K. Federlin, and R.G. Bretzel. 1994. Evidence for breed-dependent differences in porcine islets of Langerhans. Transplant. Proc. 26:616-617.

20. Van Deijnen, J.H.M., C.E. Hulstaert, G.H.J. Wolters, and R. van Schilfgaarde. 1992. Significance of the peri-insulinar extracellular matrix for islet isolation from the pancreas of the rat, dog, pig, and man. Cell Tissue Res. 267:139146

21. Marchetti, P., E.H. Finke, C. Swanson, A. Gerasimidi-Vazeou, D.W. Scharp, R. Navalesi, and P.E. Lacy. 1992. The potential of porcine islet xenotransplantation in the therapy of diabetes. Diab. Nutr. Metab. 5(Suppl. 1): $151-154$.

22. Asplund, K., S. Westman, and C. Hellerström. 1969. Glucose stimulation of insulin secretion from the isolated pancreas of foetal and new born rats. Diabetologia. 5:260-262.

23. Asplund, G. 1973. Dynamics of insulin release from the foetal and neonatal rat pancreas. Eur. J. Clin. Invest. 3:338-344.

24. Rhoten, W.B. 1980. Insulin secretory dynamics during development of rat pancreas. Am. J. Physiol. 239:E57-E63.

25. Hole, R.L., M.C.M. Pian-Smith, and G.W.G. Sharp. 1988. Development of the biphasic response to glucose in fetal and neonatal rat pancreas. Am. J. Physiol. 254:E167-E174.

26. Tuch, B.E., A. Jones, and J.R. Turtle. 1985. Maturation of the response of human fetal pancreatic explants. Diabetologia. 28:28-31.

27. Brit, L.D., P.C. Stojeba, C.R. Scharp, M.H. Greider, and D.W. Scharp. 1981. Neonatal pig psuedo-islets. A product of selective aggregation. Diabetes. 30:580-583.

28. Archer, F.J. 1983. Monolayer culture of neonatal pig pancreatic islet cells. Diabetologia. 24:185-190.

29. Korbutt, G.S., and D.G. Pipeleers. 1992. Cold storage of the rat pancreas before purification of islet $\beta$-cells. Diabetes. 41:299-307.

30. Pipeleers, D.G., P.A. In't Veld, M. Van De Winkel, E. Maes, F.C. Schuit, and W. Gepts. 1985. A new in vitro model for the study of pancreatic A and B cells. Endocrinology. 117:806-816.

31. Pipeleers, D.G., and M.A. Pipeleers-Marichal. 1981. A method for the purification of single A, B and D cells and for the isolation of coupled cells from 
isolated rat islets. Diabetologia. 20:654-663.

32. Pipeleers, D.G., M. Pipeleers-Marichal, J.-C. Hannaert, M. Berghmans, P.A. In't Veld, J. Rozing, M. Van De Winkel, and W. Gepts. 1991. Transplantation of purified islet cells in diabetic rats. I. Standardization of islet cell grafts. Diabetes. 40:908-919.

33. Korbutt, G.S., and Pipeleers' D.G. 1993. Rat pancreas preparation for cold storage and subsequent islet cell isolation. Transplantation (Baltimore). 56: 500-503.

34. Pipeleers, D.G. 1992. Composition of islet grafts. Diab. Nutr. Metab. 5(Suppl. 1):29-32.

35. Ricordi, C. 1991. Quantitative and qualitative standards for islet isolation assessment in humans and large mammals. Pancreas. 6:242-244.

36. Alumets, J., R. Hakanson, and F. Sundler. 1983. Ontogeny of endocrine cells in porcine gut and pancreas. An immunocytochemical study. Gastroenterology. 85:1359-1372.

37. Clark, S.A., and W.L. Chick. 1990. Islet cell culture in defined serumfree medium. Endocrinology. 126:1895-1903.

38. Ling, Z., J.C. Hannaert, and D. Pipeleers. 1994. Effect of nutrients, hormones and serum on survival of rat islet beta cells in culture. Diabetologia. 37: $15-21$

39. Rabinovitch, A., B. Blondel, T. Murray, and D.H. Mintz. 1980. Cyclic adenosine-3', ,' $^{\prime}$-monophosphate stimulates islet $\mathrm{B}$ cell replication in neonatal rat pancreatic monolayer cultures. J. Clin. Invest. 66:1065-1071.
40. Swenne, I., A.J. Bone, S.L. Howell, and C. Hellerström. 1980. Effects of glucose and amino acids on the biosynthesis of DNA and insulin in fetal rat islets maintained in tissue culture. Diabetes. 29:686-692.

41. Hellerström, C., and I. Swenne. 1991. Functional maturation and proliferation of fetal pancreatic $\beta$-cells. Diabetes. 40(Suppl. 2):89-93.

42. Sandler, S., and A. Andersson. 1986. Long-term effects of exposure of pancreatic islets to nicotinamide in vitro on DNA synthesis, metabolism and B-cell function. Diabetologia. 29:199-202.

43. Schein, P.S., D.A. Cooney, and M.L. Veron. 1967. The use of nicotinamide to modify the toxicity of streptozotocin diabetes without loss of antitumor activity. Cancer Res. 27:2324-2332.

44. Sandler, S., M. Welsh, and A. Andersson. 1983. Streptozotocin-induced impairment of islet B-cell metabolism and its prevention by a hydroxyl radical scavenger and inhibitors of poly(ADP-ribose) synthetase. Acta Pharmacol. Toxicol. 53:392-400.

45. Yamada, K., K. Novaka, T. Hanafusa, T. Miyazaki, H. Toyoshima, and S. Tarui. 1987. Preventive and therapeutic effects of large-dose nicotinamide injections on diabetes associated with insulitus. An observation in nonobese diabetic (NOD) mice. Diabetes. 31:749-753.

46. Otonkoski, T., G.M. Beattie, M.I. Mally, C. Ricordi, and A. Hayek. 1993. Nicotinamide is a potent inducer of endocrine differentiation in cultured human fetal pancreatic cells. J. Clin. Invest. 92:1459-1466. 